\title{
Parentification - its direction and perceived benefits in terms of connections with late adolescents' emotional regulation in the situation of marital conflict
}

\author{
Judyta Borchet ${ }^{A, B, C, D, E, F}$, Aleksandra Lewandowska-Walter ${ }^{A, C, D, E, F}$ \\ Institute of Psychology, University of Gdansk, Gdansk, Poland
}

\section{BACKGROUND}

Parentification means distortion of the roles between family members. A child performs adult tasks and responsibilities for his siblings and/or parents. The aim of the study was to extend the knowledge about parentification and its connections with parental conflict as well as strategies of coping with parental conflict in the group of late adolescents who live with their parents or live on their own.

\section{PARTICIPANTS AND PROCEDURE}

The empirical evidence consisted of the results of $264 \mathrm{vol}-$ unteer late adolescents. Two questionnaires were used in the study. The first one was the experimental version of the Polish adaptation of Hooper's Parentification Inventory. It is a scale that enables one to assess the intensity of parentification levels that are judged retrospectively by the subject. The second tool was the experimental version of the Polish adaptation of Davies' and Forman's Security in the Interparental Subsystem Scale - Child Re- port. The scale examines children's reactions to parental conflict.

RESULTS

The obtained results suggest that intensity of parental conflict and strategies of coping with it influence parentification characteristics. The connections seem to be different in two adolescent groups - those who still live with their parents and those who decided to live on their own.

\section{CONCLUSIONS}

Thus, parental conflict may foster tightening of the family bonds and intensify parentification at the same time. On the other hand, in order to separate and break excessive family ties, adolescents may move out of the family house.

\section{KEY WORDS}

late adolescence; family roles; emotional regulation; marital conflict

CORRESPONDING AUTHOR - Aleksandra Lewandowska-Walter, Ph.D., Institute of Psychology, University of Gdansk,

4 Bażyńskiego Str., 80-309 Gdansk, Poland, e-mail: psyalw@ug.edu.pl

AUthors' CONTRIBUtion - A: Study design - B: Data collection - C: Statistical analysis - D: Data interpretation .

E: Manuscript preparation · F: Literature search · G: Funds collection

TO CITE THIS ARTICLE - Borchet, J., \& Lewandowska-Walter, A. (2017). Parentification - its direction and perceived

benefits in terms of connections with late adolescents' emotional regulation in the situation of marital conflict.

Current Issues in Personality Psychology, 5(2), 113-122. 


\section{BACKGROUND}

Parentification is a family system dysfunction involving reversing the roles between a child and his or her parents (Hooper, Marotta, \& Lanthier, 2008; Hooper, Doehler, \& Hannah, 2011; Schier, 2014) and may become an additional stressor for the family in the phase of the late adolescent's entry into adult life. The theoretical perspective taking into account the life cycle of a family helps to understand the individual human development process in the broader context of his interactions with other family members and in response to changes within the system and outside of it. According to the concept of Carter and McGoldrick (1989), the stress suffered by adults and children reaches the highest intensity at the moment of transition from one phase to another in the cycle of family development. At that time there is a higher probability of the occurrence of problems that are a consequence of difficulties in completing development tasks at the level of the whole system, as well as the individual development of its members. The development tasks during late adolescence include becoming financially and emotionally independent from the family and establishing self-responsibility. Stressors already existing in the family, such as conflict between parents or inverted hierarchy contributing to the fact that a child takes care of parents and siblings, may result in the postponement of making decisions related to initiation of independent life by a young man. Therefore, it seems reasonable to look into mechanisms of family processes' impact on the late adolescents in two groups depending on whether they still live with their parents or already live an independent life.

Parentification manifests itself in taking care of family members in a way adverse for a child and being burdened with family responsibilities. In such a situation, a child is providing care to his or her parents instead of being cared for by them (Schier, 2010; Hooper et al., 2011). Parentification may occur in emotional or instrumental form. Instrumental parentification refers to being concerned about family living conditions (Hooper et al., 2008; Hooper \& Wallace, 2010; Schier, 2010; Hooper et al., 2011; Schier, 2014). It manifests in physical help that a child devotes to his or her family. The child does the house chores and organizes the everyday family life (Hooper et al., 2011). Emotional parentification refers to emotional and social needs of the family members being fulfilled by the child. It may manifest in being watchful of family members' moods, caring about their comfort or being a scapegoat or a mediator between family members when conflict occurs (Schier, 2010; Hooper et al., 2011). Parentification may also be divided in terms of its consequences, which may be constructive or destructive for a child. Parentifica- tion is constructive when it has a positive impact on the child's development. It may happen for instance when performing certain functions and roles makes the child feel important, helpful and needed. It builds his or her self-competence and feeling of agency and directs the child towards focusing on the future (Schier, 2014). On the other hand, parentification is destructive when the child is so overwhelmed with adult responsibilities that he or she cannot perform his or her own developmental tasks (Schier, 2010). A situation which exceeds the child's capabilities and resources may result in various negative consequences such as substance abuse (Chase, 1998 after: Hooper et al., 2008), mental disorders (Jones \& Wells, 1996 after: Hooper et al., 2008), difficulties in relationships (Valleau, 1995 after: Hooper et al., 2008) and poor future parental skills (Boszormenyi-Nagy \& Spark, 1973; Bowen, 1978; Chase, 1998 after: Hooper et al., 2008). It is worth mentioning that another division is proposed by Hooper (2009; Hooper \& Wallace, 2010) in the concept of her measure called Parentification Inventory. The method distinguishes to whom the parentified processes are directed (siblings or parents) and also includes a subscale which measures the perceived benefits of parentification. Also the Polish researcher Schier $(2010,2014)$ notes that it is crucial whom the child is taking care of. Depending on whether it will be a mother, father, sibling(s), or the entire family at the same time, it will have a different impact on the duties performed by the child and the child's development (Schier, 2010).

This approach seems to be very relevant to Polish culture. According to Schier (2014) social approval for parentification may take root, for example, in strong Polish cultural values such as unconditional respect for parents (i.e. regardless of how they treat their children), ethos of the brave children as well as perceiving children as their parents' property. According to those beliefs, adolescents and children may be expected to care for their parents and siblings. On the other hand, Szlendak (2010) draws attention to the fact that parents in Poland after their children begin adult life realistically assess their capabilities, tending to expect material support and putting the emotional support on the shoulders of their friends. In addition, tensions and conflicts that occurred in the family in the past do not necessarily have a negative impact on the motivation of children to help their parents in Poland.

Parental conflict is one of the situations in which parentification may occur. In the face of parental conflict, the child may assume the role of caregiver to both parents or siblings. The strength and form of parental conflict is more strongly connected with problems and symptoms observed in children than the consequences of a divorce (Jouriles, Murphy, \& O'Leary, 1989). Each conflict has integrative and disintegrative elements for the family. For the pa- 
rental relationship and child's development it is important which of those two elements is predominant (Białyszewski, 1983; Ryś, 1994). Behavior disorders among children who experience parental conflict depend on many factors. One of them is adults' coping strategies (Goeke-Morey, Cummings, \& Papp, 2007). Parental lack of effective coping strategies prevents the child from learning how to regulate his or her own emotions (Schore, 1994; Kerns, Abraham, Schlegelmilch, \& Morgan, 2007; Cooper, Hoffman, Powell, \& Marvin, 2005). Cummings and Davies describe a few ways that children react to parental conflict, which take the form of 'the loud scream' or 'the silent scream' (2010). 'The loud scream' may take the form of behavioral dysregulation, which means arousal manifesting in hyperactivity and losing control over one's behavior. Secondly, 'the loud scream' may take the form of involvement, which means trying to interfere with the parental confrontation. 'The silent scream' manifests in either emotional reactivity, understood as a prolonged state of emotional tension and anxiety, or avoidance, which may be understood as a strategy used in order to get away from parental conflict and its negative consequences (Cummings \& Davies, 2010).

The relationship between the occurrence of parental conflict and difficulties in children's functioning appears to be linked to the developmental level. From a developmental perspective, every stage of a child's life poses particular challenges that the child has to meet in order to obtain better competences for the next life stage (Cicchetti, 1993). The child's exposure to parental conflict may disturb the harmonious progress of solving developmental tasks, which in turn leads to the formation of maladaptive patterns of the child's functioning. Additionally, every improperly solved problem makes it more difficult for the child to succeed in subsequent life stages (Cicchetti, 2006). A particular age may predispose the child to experiencing the parental conflict situation more intensely and trigger the occurrence of a certain class of disorders. According to Wallerstein and Blakeslee (2005), the early adolescence stage is an "unpredictable period." On one hand, as compared to a younger child, an adolescent is better at assessing who is responsible for the family conflict and has more developed skills of solving loyalty conflicts and using external sources of support in family crisis situations (Hetherington, 1993). On the other hand, a strong conflict between parents may cause a whole repertoire of violent reactions and intensify the symptoms of emotional dysregulation typical for the period of adolescence. Franke (1983) gave a name to the apparently mature attitude, observed in adolescents faced with family crises stemming from conflicts between parents, that involves taking adult roles or attaining empowerment prematurely and moving away from the family home. A conflicted atmosphere in a mar- ried dyad is frequently the reason why the oldest child, usually aged more than 12 , takes the difficult role of a person loyal to the parent who requires instrumental or emotional support, or strives to protect younger siblings. Thus, the child experiences parentification, which means having to fulfill tasks inappropriate to one's developmental age. The adolescent is then forced to begin her adult life earlier than her peers whose families provide them with the feeling of safety thanks to competent adult care. For fear of the deterioration of relations among family members, the young person often postpones her leaving of the family of origin because she feels obliged to take care of her parents and/or siblings. Thus, she does not take on the roles and tasks of adulthood on time. However, sometimes young people, burdened with household duties resulting from a reversed family hierarchy, make a radical change in their lives and abandon their families through physical separation and emotional cut-off (Bowen, 1987).

Having siblings may perform miscellaneous functions in a situation when parents are in conflict. First of all, having siblings may be a protective factor in the view of parental conflict. A brother or a sister may become a child's secondary attachment figure when parents are engaged in their conflict (Bowlby, 2007). On the other hand, conflicts between siblings may escalate parental conflicts, which in return negatively affects children and causes damage in parentchild relations and in other relationships within the family (Stocker \& Youngblade, 1999). Relationships with siblings also become then much less friendly (Dunn \& Davies, 2001 for Cummings \& Davies, 2010). Parental hostility towards their children seems to be the mediator between parental conflict and relationships between siblings (Stocker \& Youngblade, 1999) and attempts to pull the children into coalitions, which increases the rivalry between them (Howes \& Markman, 1989).

The present research aimed to extend the knowledge about parentification and its connections with parental conflict and adolescents' strategies of coping with parental conflict. It is particularly interesting to compare these family processes between people in late adolescence who still live with their parents and those who have left the family home. Szlendak (2010) describes two paths of entering adulthood. In one of them, leaving home, entering the labor market and starting one's own family were simultaneous events, whereas according to the second model, these events are spaced apart in time and normally start with taking up a job, which allows financial independence from one's parents. Because of the prolongation of the education process and difficulties in getting a job in Poland, we can observe an increasing number of so-called "fledglings", who are adults who do not want to "leave the nest" and begin an independent life (Fitzpatrick, Błażek, Kaźmierczak, \& Le- 
wandowska-Walter, 2014). Poland also has one of the highest age rates for adult children living at home (Boni \& Szafraniec, 2011). Therefore, it is important to consider whether outside of sociological factors, the psychological mechanisms expressed by parentification, namely the necessity to support parents, take care of siblings or act as a family buffer in the face of parental conflict, also distinguish the people leaving the house in accordance to the rhythm of the family life cycle and those postponing such a decision. Formulating a thesis in this case is a difficult task, as in the case of late adolescents who have left the family home it can be expected that on one hand they will conduct a development task in accordance with the individual rhythm and family life cycle, but on the other hand they could opt for quick independence in order to cut themselves off from the necessity of acting as a guardian of the other members of the family. On the other hand, late adolescents who still live with their parents can enjoy the comforts of life offered to them by their parents or remain in the family home due to serving roles described as parentification. Therefore, a few questions were put:

1. Are there group differences in parentification characteristics among individuals who live with parents and individuals who live separate from parents?

2A. For individuals who live with parents, how do parental conflict and coping strategies contribute to parent-focused parentification?

2B. For individuals who live separately from parents, how do parental conflict and coping strategies contribute to parent-focused parentification?

3A. For individuals who live with parents, how do parental conflict and coping strategies contribute to parentification benefits?

3B. For individuals who live separately from parents, how do parental conflict and coping strategies contribute to parentification benefits?

4A. For individuals who live with parents, how do parental conflict and coping strategies contribute to sibling-focused parentification?

4B. For individuals who live separately from parents, how do parental conflict and coping strategies contribute to sibling-focused parentification?

\section{PARTICIPANTS AND PROCEDURE}

\section{PARTICIPANTS}

The empirical evidence consisted of the results of two hundred sixty-four volunteers. The group consisted of $87.50 \%$ women and $12.50 \%$ men. They were around 21 years old $(M=21.39, S D=2.52)$. The majority of late adolescents were during their university studies $(84.50 \%)$. The rest of them had higher $(11.40 \%)$ or secondary education $(4.20 \%)$. The research group con- sisted of people who were in informal relationships $(52.70 \%)$ or were single $(43.60 \%)$. Only $3.80 \%$ of the group were married. Most of the participants were unemployed (55.70\%), but some of them had a fulltime $(17.40 \%)$ or part-time job (26.90\%). Only $17.40 \%$ of the group were only children. Adolescents who did not have siblings were excluded while counting the results of the Sibling-focused Parentification Subscale. Adolescents who lived with their parents accounted for $61.70 \%$ of the group, while those who lived on their own constituted $38.30 \%$ of the group.

\section{MEASURES}

The adolescents who participated in the research filled in Hooper's Parentification Inventory (2009) in the experimental version of the Polish adaptation by Lewandowska-Walter and Borchet (2015) and the experimental version of the Polish adaptation of Davies' and Forman's Security in the Interparental Subsystem (SIS) Scale - Child Report (Winnicka, 2013; Lewandowska-Walter \& Waruszewska, in press).

SIS Scale - Child Report. The scale was developed in 2002 by Davies and Forman. The scale examines children's reactions to parental conflict (Cummings \& Davies, 2010). The theoretical basis for the tool was the emotional security hypothesis, which assumes that the emotional security posed by the parental subsystem is the basic mechanism which moderates the relation between parental conflict and the child's possibilities to adapt to it (Davies, Forman, Rasi, \& Stevens, 2002). Due to this theory, difficulties for children in maintaining emotional security stem from being exposed to destructive experiences connected with parental conflict (Davies et al., 2002). Such experiences may result in emotional insecurity which may increase the risk of psychological problems (Cummings \& Davies, 1996 after: Davies et al., 2002). The SIS Scale - Child Report has seven subscales. The reliability indicators for this study are presented in parentheses. Emotional reactivity (Cronbach's $\alpha$ : .85) means frequent, prolonged and deregulated experience of distress. Behavioral dysregulation represents physiological arousal and lack of control (Cronbach's $\alpha: .43$ ). Due to the low reliability of this scale its results were not taken into consideration. Avoidance refers to strategies used to get away from parental conflict and its aftermath (Cronbach's $\alpha: .81$ ). Involvement describes tendencies to be emotionally or behaviorally engaged in parental conflict (Cronbach's $\alpha$ : .66). Constructive family representations as a scale means the evaluation of the parental conflict as mild and constructive for the family (Cronbach's $\alpha$ : .89), whereas Destructive family representations are the assessment of negative consequences of parental conflict for the family system (Cronbach's $\alpha$ : .79). Conflict spillover representations refers to assessing 
how much the parental conflict negatively influences the child's well-being (Cronbach's $\alpha$ : .73) (Cummings \& Davies, 2010).

Parental conflict evaluation. Additionally, late adolescents were asked to evaluate how they perceive their parents' conflict. They had to choose a point on a Likert-type scale from 1 to 5 , where 1 meant lack of conflict and tension, and 5 meant strong conflict and tension perceived between one's parents.

Parentification Inventory. Participants completed the experimental version of the Polish adaptation of the Parentification Inventory (Hooper, 2009) by Lewandowska-Walter and Borchet (2015). It is a scale that enables one to assess the intensity of parentification levels that are judged retrospectively by the subject. Its theoretical basis lies in family system theory (Hooper et al., 2011). It consists of 3 sub-scales. The reliability indicators of the subscales for this study are presented in parentheses. Parent-focused parentification refers to the roles and responsibilities that are appropriate for the adults but usually the child is performing them for his or her parents (Cronbach's $\alpha$ : 80). Sibling-focused parentification refers to the roles and responsibilities that are appropriate for the adults but the child is performing them for his or her siblings (Cronbach's $\alpha: .58)$. Perceived benefits of parentification are the positive thoughts and feelings which are experienced by the child because of performing adult roles and responsibilities for his or her family (Cronbach's $\alpha:$.81). The work on the Polish adaptation of this tool still continues. Based on the preliminary analyses, we can say that the indicators are promising and the three-factor model of the original scale is to be confirmed. However, the scale seems to be culturally dependent, as was confirmed by the differences between the Spanish version and the original American tool (Hooper, 2014).

\section{RESULTS}

The multi-factor analysis of variance (ANOVA) was conducted to assess whether it is reliable to test the group differences. In order to answer the research questions number 2, 3, and 4 stepwise regression models were tested. The dependent variables were
Parent-focused parentification, Siblings-focused parentification and Perceived benefits of parentification. The independent variables were intensity of parental conflict and strategies of coping with parental conflict. The grouping variable was living with one's parents or living on one's own. The tables present only statistically significant results.

\section{GROUP DIFFERENCES}

Significant differences between the individuals who lived with their parents and those who lived on their own were obtained in Sibling-focused parentification $\left(F(1)=4.92, p=.027, \eta^{2}=.02\right)$. The adolescents who lived on their own had a higher level of parentification towards siblings than those who lived with their parents $(M=2.51, S D=0.50$ vs. $M=2.35, S D=0.52)$. The results of the analysis are presented in Table 1 .

\section{PARENT-FOCUSED PARENTIFICATION}

In the group of adolescents living with their parents the first step was to examine the influence of parental conflict on parentification towards parents. In the second step strategies of coping with the parental conflict were added to the model. Below, results for the dependent variable Parent-focused parentification are presented (Table 2).

In the view of parental conflict, the intensity of parental conflict does not affect the amount of care and concern given to the parents for the adolescents who lived with their parents. After adding the second predictor (strategies of coping with parental conflict) the model became statistically significant. The significant predictors were Avoidance $(\beta=-.35, p=.006)$ and Involvement $(\beta=.34, p=.010)$. These two results are consistent, and it shows that when the parents are conflicted the adolescents tend to engage in conflict.

In the group of adolescents who lived on their own the first step was to examine the influence of parental conflict on parentification towards parents. In the second step strategies of coping with the parental conflict were added to the model. Below, results for the dependent variable Parent-focused parentification are presented (Table 3).

Table 1

Differences in parentification characteristics among individuals who live with parents and individuals who live separately from parents

\begin{tabular}{lcccc}
\hline Source & $F$ & $d f$ & $p$ & $\eta^{2}$ \\
\hline Parent-focused parentification & 1.94 & 1 & .165 & .01 \\
Sibling-focused parentification & 4.92 & 1 & .027 & .02 \\
Perceived benefits of parentification & 1.34 & 1 & .247 & .01 \\
\hline
\end{tabular}


Table 2

Intensity of parental conflict and strategies of coping with parental conflict as predictors of Parent-focused parentification in the group of adolescents living with their parents

\begin{tabular}{lcccccc}
\hline Model & Predictors & $R$ & $R^{2}$ & Adjusted $R^{2}$ & $F(d f)$ & $p$ \\
\hline 1 & Intensity of parental conflict & .02 & .00 & -.01 & $0.05(1,99)$ & .818 \\
& Intensity of parental conflict & & & & & \\
2 & $\begin{array}{c}\text { Strategies of coping with } \\
\text { parental conflict }\end{array}$ & .47 & .22 & .16 & $3.32(8,92)$ & .002 \\
\hline
\end{tabular}

Table 3

Intensity of parental conflict and strategies of coping with parental conflict as predictors of Parent-focused parentification in the group of adolescents living on their own

\begin{tabular}{lcccccc}
\hline Model & Predictors & $R$ & $R^{2}$ & Adjusted $R^{2}$ & $F(d f)$ for $R^{2}$ & $P$ \\
\hline 1 & Intensity of parental conflict & .28 & .08 & .07 & $13.13(1,161)<.001$ \\
& $\begin{array}{l}\text { Intensity of parental conflict } \\
2\end{array}$ & $\begin{array}{c}\text { Strategies of coping with } \\
\text { parental conflict }\end{array}$ & .50 & .25 & .21 & $6.33(8,154)<.001$ \\
\hline
\end{tabular}

In view of parental conflict, both the intensity of parental conflict and strategies of coping with parental conflict affect the amount of care and concern given to the parents for the adolescents who lived on their own. The first model including the intensity of parental conflict $(\beta=.28, p<.001)$ was statistically significant. In the second model the significant predictors were Avoidance $(\beta=-.31, p=.001)$ and Involvement $(\beta=.29, p=.001)$. These two results are consistent because the adolescents are not avoiding the situation and they get involved in it.

\section{PERCEIVED BENEFITS OF PARENTIFICATION}

In the group of adolescents living with their parents the first step was to examine the influence of parental conflict on Perceived benefits of parentification. In the second step strategies of coping with the parental conflict were added to the model.

Below, results for the dependent variable Perceived benefits of parentification are presented (Table 4).
In the view of parental conflict, for the adolescents who lived with their parents both the intensity of parental conflict and the strategies of coping with parental conflict affect the amount of Perceived benefits of parentification. The first model including the intensity of parental conflict $(\beta=-.45, p<.001)$ was statistically significant. In the second model the significant predictors were Emotional reactivity $(\beta=.36, p=.001)$, Avoidance $(\beta=.26, p=.011)$ and Constructive family representations $(\beta=.58, p<.001)$. The results show that adolescents who live with their parents and perceive more benefits of experiencing parentification tend to cope with their parents' conflict by avoiding it, being emotionally reactive and vulnerable. Apart from that, they try to keep positive representation of their family despite the conflict and problems in the family.

In the group of adolescents living on their own the first step was to examine the influence of parental conflict on Perceived benefits of parentification. In the second step the strategies of coping with the parental conflict were added to the model. Below, results for the dependent variable Perceived benefits of parentification are presented (Table 5).

Table 4

Intensity of parental conflict and strategies of coping with parental conflict as predictors of Perceived benefits of parentification in the group of adolescents living with their parents

\begin{tabular}{lcccccc}
\hline Model & Predictors & $R$ & $R^{2}$ & Adjusted $R^{2}$ & $F(d f)$ for $R^{2}$ & $P$ \\
\hline 1 & Intensity of parental conflict & .45 & .20 & .19 & $24.92(1,99)$ & $<.001$ \\
& Intensity of parental conflict & & & & & \\
2 & $\begin{array}{c}\text { Strategies of coping with pa- } \\
\text { rental conflict }\end{array}$ & .70 & .48 & .44 & $10.63(8,92)<.001$ \\
\hline
\end{tabular}


Table 5

Intensity of parental conflict and strategies of coping with parental conflict as predictors of Perceived benefits of parentification in the group of adolescents living on their own

\begin{tabular}{lcccccc}
\hline Model & Predictors & $R$ & $R^{2}$ & Adjusted $R^{2}$ & $F(d f)$ for $R^{2}$ & $p$ \\
\hline 1 & $\begin{array}{c}\text { Intensity of parental } \\
\text { conflict }\end{array}$ & .38 & .15 & .14 & $27.63(1,161)$ & $<.001$ \\
& $\begin{array}{c}\text { Intensity of parental } \\
\text { conflict }\end{array}$ & & & & & \\
2 & $\begin{array}{c}\text { Strategies of coping with } \\
\text { parental conflict }\end{array}$ & .57 & .33 & .29 & $9.30(8,154)$ & $<.001$ \\
& & & & & \\
\hline
\end{tabular}

In view of parental conflict, for the adolescents who lived on their own both the intensity of parental conflict and the strategies of coping with parental conflict affect the amount of Perceived benefits of parentification. The first model including the Intensity of parental conflict $(\beta=-.38, p<.001)$ was statistically significant. In the second model Constructive family representations $(\beta=.37, p<.001)$ was the only significant predictor. The better the adolescents who lived on their own think about their family despite the conflict, the more benefits of parentification they notice.

\section{SIBLING-FOCUSED PARENTIFICATION}

In the group of adolescents living with their parents the first step was to examine the influence of parental conflict on parentification towards siblings. In the second step the strategies of coping with the parental conflict were added to the model. Below, results for the dependent variable Sibling-focused parentification are presented (Table 6).

In view of parental conflict, for the adolescents who lived with their parents the intensity of parental conflict does not affect the amount of care and concern given to their siblings. After adding the second predictor (strategies of coping with parental conflict) the model became statistically significant. The significant predictors were Emotional reactivity $(\beta=.41$, $p=.007)$ and Involvement $(\beta=.37, p=.013)$. The results show that adolescents who are living with their parents and performing more parentification duties to their sibilings, tend to cope with their parents' conflict by getting involved with it and being emotionally reactive and vulnerable.

In the group of adolescents who lived on their own the first step was to examine the influence of parental conflict on parentification towards siblings. In the second step the strategies of coping with the

Table 6

Intensity of parental conflict and strategies of coping with parental conflict as predictors of Sibling-focused parentification in the group of adolescents living with their parents

\begin{tabular}{|c|c|c|c|c|c|c|}
\hline Model & Predictors & $R$ & $R^{2}$ & Adjusted $R^{2}$ & $F(d f)$ for $R^{2}$ & $p$ \\
\hline 1 & $\begin{array}{c}\text { Intensity of parental } \\
\text { conflict }\end{array}$ & .15 & .02 & .01 & $1.89(1,80)$ & .173 \\
\hline 2 & $\begin{array}{l}\text { Intensity of parental } \\
\text { conflict } \\
\text { Strategies of coping with } \\
\text { parental conflict }\end{array}$ & .56 & .32 & .24 & $4.23(8,73)$ & $<.001$ \\
\hline
\end{tabular}

Table 7

Intensity of parental conflict and strategies of coping with parental conflict as predictors of Sibling-focused parentification in the group of adolescents living on their own

\begin{tabular}{ccccccc}
\hline Model & Predictors & $R$ & $R^{2}$ & Adjusted $R^{2}$ & $F(d f)$ for $R^{2}$ & $p$ \\
\hline 1 & $\begin{array}{c}\text { Intensity of parental conflict } \\
\text { Intensity of parental conflict }\end{array}$ & .00 & .00 & -.01 & $0.00(1,134)$ & .976 \\
2 & $\begin{array}{c}\text { Strategies of coping with } \\
\text { parental conflict }\end{array}$ & .29 & .08 & .03 & $1.43(8,127)$ & .190 \\
\hline
\end{tabular}


parental conflict were added to the model. Below, results for the dependent variable Sibling-focused parentification are presented (Table 7).

In view of parental conflict, for the adolescents who lived on their own neither the intensity of parental conflict nor the strategies of coping with parental conflict affect the amount of care and concern given to their siblings.

\section{DISCUSSION}

The aim of this study was to extend the knowledge about parentification among late adolescents and its connections with parental conflict and the strategies of coping with parental conflict they use. The first question was aimed to test the group differences in parentification characteristics between adolescents who lived with their parents and those who did not. Because there was one significant difference in terms of sibling-focused parentification the authors decided that it is evidence that the parentification process may be different in those two groups, which made running the analyses distinctly reliable. The second question concerned the impact of the intensity of parental conflict on parent-focused parentification in the case of late adolescents who live with their parents or separately. In the analysis of replies to the third question it was verified whether the strategies of coping with parental conflict influence perceived benefits of parentification in late adolescence in both groups. The fourth question was whether the strategies of coping with parental conflict influence sibling-focused parentification differently in the case of late adolescents who live with their parents or separately.

In the light of the results one can state that parental conflict and strategies of coping with parental conflict influence parentification characteristics (its direction towards parents or siblings and its perceived advantages). Moreover, the discussed processes occur rather differently in the group of adolescents who live with their family of origin and those who live on their own and do not share the household with their family of origin. When the adolescent lives with the parents, the more he or she copes with the parental conflict with engaging in it and the less he or she avoids it, the more he or she tries to take care of the conflicted parents. The weaker the conflict of the mother and father is, the more the adolescent copes with it by experiencing prolonged distress, the less he or she avoids the parental conflict, the more he or she evaluates the parental conflict as constructive and the more benefits of parentification he or she notices. Additionally, adolescents who cope with parental conflict with emotional reactivity and engage in the conflict are more involved with taking care of their siblings. If the adolescent lives on his/ her own, parentification towards parents is connected with the intensity of parental conflict and strategies of coping with it such as involvement and not avoiding the conflict (which is consistent with the previous result). The weaker the parental conflict is and the more constructively the adolescent judges it, the more benefits of parentification the adolescent perceives. Neither the intensity of parental conflict nor the strategies of coping with parental conflict affects the amount of care and concern given to their siblings. What is more, the level of parentification towards siblings was significantly different between adolescents who shared the household with their parents and those who lived on their own. Taking that into consideration it may be concluded that parental conflict and ways of coping with it may not be strong predictors of how much concern and care is being given to siblings, and other connections and predictors are to be sought. Perhaps the quality of relations between siblings may be the one that is crucial to the level of parentification focused on siblings.

For both groups - the adolescents who share the household with their parents and the adolescents who lived on their own - it was noticeable that the more they engage in the parental conflict, the more parentified they are. It may be due to the fact that involvement in the parental conflict tightens the family ties and builds the loyalties and coalitions. Moreover, the adolescent may be worried about the parents, and that may trigger his or her over-concern about the parents. Additionally, for adolescents who live outside the family house the intensity of parental conflict influences their parentification towards parents. Leaving the family home seems to change a lot in relationships between siblings, even if their parents' conflict is not involved. After moving out from the family house late adolescents may start being over-concerned about their siblings. That may occur due to the fact that they are no longer able to provide help for their siblings in their everyday life as much as they did in the past. While experiencing parental conflict late adolescents tend to care about their siblings, they parentify their siblings and are more emotionally engaged in parental conflict. Perhaps moving out was an attempt to cut off the excessive family ties (enmeshment) and overwhelming responsibilities, as explained by Bowen in his concept of intergenerational transmission (1987). At the same time, it may be the way to separate from the family and individuate, which was not available while living with the family when the roles were reversed. Living with parents and taking care of them is one of the risk factors which extends the process of entering adulthood (com. Wojciechowska, 2005). Moreover, those who stay at home may not have enough space to start their own life because of feeling responsible for their siblings and conflicted parents. However, moving out and cutting family ties seems to be an ineffective way 
of removing the burden of responsibility caused by performing family roles.

In terms of perceived benefits of parentification, there was a similar pattern in both groups. The weaker the adolescents assessed their parents' conflict and the more they described it as constructive, the more benefits of parentification they perceived. This means that it is possible to perceive the benefits of a difficult situation, which is basically parentification, if the parental conflict has a positive impact on family life. This result is consistent with actual knowledge. Young people learn from their parents how to solve conflicts functionally (Pryor \& Pattison, 2007). Lack of such patterns makes it difficult to acquire constructive ways of conflict solving and to form correct manners of communicating (com. Harwas-Napierała, 2008). Gaining knowledge how to resolve conflicts effectively may be the reason the adolescents find such situations beneficial for them. Moreover, the research conducted by Borchet, Lewandowska-Walter and Rostowska (2016) suggests that adolescents who are satisfied with their family life are more inclined to positively reformulate parentification experienced by them and to notice more benefits connected with it.

Obviously, the study had some limitations. First, the majority of the group were women, which means that the results should be generalized and interpreted with caution. Moreover, the participants participated in the survey voluntarily. Additionally, the study had methodological limitations. There were experimental methods used which were not yet fully adapted to Polish conditions, and the intensity of parental conflict was measured only on a Likert scale from 1 to 5 . However, those limitations stem from the fact that there were neither Polish nor other adapted similar methods available. Therefore, the researchers decided to use the experimental methods so that they can not only answer their research questions but also test the methods. Because there were significant relations between the variables, the study should be repeated after completion of the adaptation process.

The study also had some advantages. The main strength was its novelty in terms of Polish family psychology due to the fact that most research on parentification has been carried out in the United States. Taking it all into consideration, regardless of the mentioned limitations, the results encourage us to conduct further research on parentification, especially in terms of parental conflict and coping with it.

\section{References}

Białyszewski, H. (1983). Teoretyczne problemy sprzeczności i konfliktów społecznych [Theoretical problems of contradictions and social conflicts]. Warszawa: PWN.
Borchet, J., Lewandowska-Walter, A., \& Rostowska, T. (2016). Parentification in late adolescence and selected features of the family system. Health Psychology Report, 4, 116-127. doi: https://doi. org/10.5114/hpr.2016.55921

Boni, M., \& Szafraniec, K. (2011). Mtodzi 2011 [The Young 2011]. Warszawa: Kancelaria Prezesa Rady Ministrów.

Bowen, M. (1987). Family therapy in clinical practice. New York: Jason Aronson

Bowlby, J. (2007). Przywiqzanie [Attachment]. Warszawa: Wydawnictwo Naukowe PWN.

Carter, B., \& McGoldrick, M. (1989). Overview: The Changing Family Life Cycle. In: B. Carter \& M. McGoldrick (eds.), The Changing Family Life Cycle. A Framework for Family Therapy (pp. 3-28). Boston-London-Sydney-Toronto: Allyn and Bacon Cicchetti, D. (1993). Developmental psychopathology: Reactions, reflections, projections. Developmental Review, 13, 471-502.

Cicchetti, D. (2006). Development and Psychopathology. In D. Cicchetti (ed.), Developmental Psychopathology: Theory and Method ( $2^{\text {nd }}$ ed.) (vol. 1, pp. 1-23). New York: Wiley.

Cooper, G., Hoffman, K., Powell, B., \& Marvin, R. (2005). The Circle of Security intervention: Differential diagnosis and differential treatment. In L. J. Berlin, Y. Ziv, L. M. Amaya-Jackson, \& M. T. Greenberg (eds.), Enhancing early attachments: Theory, research, intervention, and policy (pp. 127-151). New York: Guilford Press.

Cummings, E. M., \& Davies, P. T. (2010). Marital conflict and children: An emotional security perspective. New York: The Guilford Press.

Davies, P. T., Forman, E. M., Rasi, J. A., \& Stevens, K. I. (2002). Assessing Children's Emotional Security in the Interparental Relationship: The Security in the Interparental Subsystem Scales. Child Development, 73, 544-562.

Fitzpatrick, J., Błażek, M., Kaźmierczak, M., \& Lewandowska-Walter, A. (2013). Lifestyle and close relationship trends among young adults in Poland. Journal of Social and Personal Relationships, 31, 928-937.

Franke, L. (1983). Growing in divorced. New York: Linden Press.

Goeke-Morey, M. C., Cummings, E. M., \& Papp, L. M. (2007). Children and marital conflict resolution: Implications for emotional security and adjustment. Journal of Family Psychology, 21, 744-753.

Harwas-Napierała, B. (2008). Komunikacja interpersonalna $w$ rodzinie [Interpersonal communication in the family]. Poznań: Wydawnictwo UAM.

Hetherington, E. M. (1993). An overview of the Virginia Longitudinal Study of Divorce and Remarriage with a Focus on Early Adolescence. Journal of Family Psychology, 7, 39-56. 
Hooper, L. M., Marotta, S. A., \& Lanthier, R. P. (2008). Predictors of growth and distress following childhood parentification: A retrospective exploratory study. Journal of Child \& Family Studies, 17, 693705. doi: 10.1007/s10826-007-9184-8

Hooper, L. M. (2009). Parentification Inventory. Available from L. M. Hooper, Department of Educational Studies in Psychology, Research Methodology, and Counseling, The University of Alabama, Tuscaloosa, AL. 35487.

Hooper, L. M., \& Wallace, S. A. (2010). Evaluating the Parentification Questionnaire: Psychometric Properties and Psychopathology Correlates. Contemporary Family Therapy, 32, 52-68.

Hooper, L. M., Doehler, K., \& Hannah, N. J. (2011). The Parentification Inventory: Development, Validation and Cross-Validation. The American Journal of Family Therapy, 39, 226-241.

Hooper, L. M. (2014). Assessing parentification in South American college students: A factor analytic study of a Spanish version of the Parentification Inventory. Journal of Multicultural Counseling and Human Development, 42, 93-106.

Howes, P., \& Markman, H. (1989). Marital quality and child functioning: A longitudinal investigation. Child Development, 60, 1044-1051.

Jouriles, E. N., Murphy, C. M., \& O’Leary, K. D. (1989). Interspousal aggression, marital discord, and child problems. Journal of Consulting and Clinical Psychology, 57, 453-455.

Kerns, K. A., Abraham, M. M., Schlegelmilch, A., \& Morgan, T. A. (2007). Mother-child attachment in later middle childhood: Assessment approaches and associations with mood and emotion regulation. Attachment and Human Development, 9, 33-53.

Lewandowska-Walter, A., \& Borchet, J. (2015). Kwestionariusz Parentyfikacji [Parentification Inventory] (available from the authors). Institute of Psychology, University of Gdansk, Gdansk, Poland.

Lewandowska-Walter, A., \& Waruszewska, K. (in press). Uwarunkowania regulacji emocjonalnej adolescentów w obliczu konfliktu matżeńskiego porównanie funkcjonowania młodzieży z rodzin petnych oraz w sytuacji okotorozwodowej [Determinants of adolescents' emotion regulation in the face of marital conflict - the comparision of functioning of youth from intact and divorced families].

Pryor, J. E., \& Pattison, R. (2007). Adolescent's perception of parental conflict. The downside of silence. Journal of Family Studies, 13, 72-77.

Ryś, M. (1994). Konflikty w rodzinie - niszcza czy buduja? [Conflicts in the family - do they destroy or build?]. Warszawa: Centrum Metodyczne Pomocy Psychologiczno-Pedagogicznej Ministerstwa Edukacji Narodowej.
Schier, K. (2010). „Gdy dziecko staje się rodzicem” odwrócona troska, czyli zjawisko parentyfikacji w rodzinie ["When a child becomes a parent" - reversed care as a phenomenon of parentification in the family]. In: B. Tryjarska (ed.), Bliskość w rodzinie. Więzi w dzieciństwie a zaburzenia w dorostości [The cohesion of the family. Bonds in childhood and disorders in adulthood] (pp. 63-80). Warszawa: Wydawnictwo Naukowe Scholar.

Schier, K. (2014). Doroste dzieci. Psychologiczna problematyka odwrócenia ról $w$ rodzinie [Adult children. Psychological problems of roles' reversal in the family]. Warszawa: Wydawnictwo Naukowe Scholar.

Schore, A. (1994). Affect regulation and the origin of the self: The neurobiology of emotional development. New York: Brunner/Mazel.

Stocker, C. M., \& Youngblade, L. (1999). Marital conflict and Parental Hostility: Links with children's sibling and peer relationships. Journal of Family Psychology, 13, 598-609.

Szlendak, T. (2010). Socjologia rodziny. Ewolucja, historia, zróżnicowanie [Sociology of the Family. Evolution, history, diversity]. Warszawa: Wydawnictwa Naukowe PWN.

Wallerstein, J., \& Blakeslee, S. (2005). Rozwód, a co $z$ dziećmi [Divorce, and what about kids]. Poznań: Zysk i S-ka.

Winnicka, J. (2013). The determinants of adolescents' emotional regulation in the face of marital conflict - a comparison between the youth from full families and the ones in a situation of divorce. Master's thesis, Univeristy of Gdańsk, Gdańsk, Poland.

Wojciechowska, J. (2005). Okres wczesnej dorosłości. Jak rozpoznać ryzyko i jak pomagać? [The early adulthood. How to recognize the risks and how to help?]. In A. Brzezińska (ed.), Psychologiczne portrety człowieka. Praktyczna psychologia rozwojowa [Psychological portraits of a man. Applied developmental psychology] (pp. 469-502). Gdańsk: Gdańskie Wydawnictwo Psychologiczne. 